\title{
The Internet, political trust, and regime types: a cross-national and multilevel analysis
}

\author{
Yu You ${ }^{1 *}$ (D) and Zhengxu Wang ${ }^{2}$ \\ ${ }^{1}$ School of Public Affairs, Chongqing University, Chongqing, China and ${ }^{2}$ School of International Relations \& Public Affairs, \\ Fudan University, Fudan, China \\ ${ }^{*}$ Corresponding author. E-mail: fisheryouyu@gmail.com
}

(Received 11 March 2019; revised 4 August 2019; accepted 2 September 2019; first published online 16 October 2019)

\begin{abstract}
The Internet has played important roles in driving political changes around the world. Why does it help to topple political regimes in some places but improve the quality of governance in others? We found Internet usage in general leads to citizens' distrust in political institutions. Different political environments, however, can condition such trust-eroding impacts of the Internet in significantly different ways. A democracy enables citizens to connect their online behaviors and offline expression and organization, releasing political discontent while facilitating state-society communication. On the contrary, by restricting various forms of off-line expression, authoritarian regimes drive Internet-active citizens' discontent and distrust to higher levels. We use the World Values Survey data to establish these different mechanisms across democracies and authoritarian systems. Entropy balancing shows our findings to be highly robust.
\end{abstract}

Key words: Critical citizens; democratization; institutional trust; Internet use; political expression

\section{Introduction}

Since the end of the Cold War, the world has witnessed two major trends. One has been well documented, that is, the spread of democracy across the globe over the last three decades (Huntington, 1991; Diamond, 2008). The other, which has also attracted great attention, is that almost the whole world has moved irreversibly into an Internet age. These two processes of technological and social change have inspired a heated debate among social scientists, and researchers have been quick to note how these two trends intertwine with each other (see, e.g., Dahlberg, 2001; Howard, 2010; Howard and Hussain, 2011; Nisbet et al., 2012; Wolfsfeld et al., 2013). In this regard, the majority of existing research has focused on the causal direction from the Internet to political regimes, such as how the Internet plays a role in toppling authoritarian regimes or improving governance (see, e.g., Dunleavy et al., 2006; Tucker, 2007; Eltantawy and Wiest, 2011; Khondker, 2011). By contrast, not much research has examined the reverse causal linkage, that is, how different political systems affect the dynamics on the Internet. Put differently, while Internet-related politics has been widely studied, we have little knowledge regarding how democracies and non-democracies influence Internet politics differently.

Do Internet-related technologies and devices impact citizens' attitudes and behavior differently between democratic and non-democratic political systems? And, if they do, what institutional characteristics of democracies and non-democracies, respectively, lead to such different effects of the Internet on citizens' attitudes? We address these questions by focusing on the Internet's impact on citizens' trust in political institutions - known as institutional trust or political trust - across regime types. 
Examining data from the latest wave of the World Values Survey (WVS), we found that Internet use generates significant downward pressure on political trust in democracies and non-democracies alike. An important difference exists, however, with the Internet imposing less severe trust-eroding effect in democracies than it does in non-democracies. We suggest that this differentiated effect is generated by the better and freer options of political expression provided in democracies. We are able to demonstrate the operation of this mechanism by isolating the moderating effect on political trust by extra-institutional ways of expression such as petitions or demonstrations. Put differently, Internet use produces a bigger trust-eroding effect in countries with less space and avenues for free political expression. The net result is that the Internet leads to a stronger decrease in political trust in non- or less democratic countries.

The rest of the paper is structured as follows. We first discuss the literature on political trust and the political impact brought by the rise of the Internet. We argue that the Internet generates downward pressure on political trust, decreasing citizens' trust in government institutions. We will also show that, given the different institutional set-ups, such trust-dissipating effect should be less severe in democracies. The differences in expression options and spaces should mean that the distrust-enabling mechanisms were better mitigated in democracies than in non-democracies. We propose three hypotheses along the way before we turn to describe our data sources, variables, and estimation methods. The next part contains our empirical results, including reporting on robustness checks. A discussion of our research findings and conclusion follow.

\section{The Internet, political trust, and regime types}

\subsection{The trust-eroding Internet?}

Globally, the discussion on political trust has focused on the rise of 'critical citizens' as causing the decline of political trust among advanced democracies (Norris, 1999). Continuous improvement of mass education, especially higher education, and people's living standard provide the conditions for the making of critical citizens, while rise of post-materialism and self-expression as a result of socioeconomic modernization and post-modernization are likely to produce citizen activism, and to widen the gap between public expectation for government performance, all eroding institutional trust (Inglehart, 1997; Inglehart and Baker, 2000; Norris, 2002, 2011). Such a modernization process is taking place in authoritarian countries as well, with the sustained period of socioeconomic development leading to post-materialist values, which gives rise to the forming of critical citizenships (Wang and You, 2016).

Of late, the Internet has entered as a force fostering in critical citizenship, the promotion of the democratization, and the improvement of the quality of democracy (see, e.g., Norris, 2002, 2008; Nisbet and Scheufele, 2004; Lei, 2011; Nisbet et al., 2012; CHO, 2014). This is because, first, the Internet provides a pluralistic platform of information exchanges, public deliberation, and calling for collective action (Zheng and $\mathrm{Wu}, 2005$; Nisbet et al., 2012). By contrast, traditional media tend to provide selected, manufactured, and in many cases censored information to the citizens that are often passive receivers. In non-democracies, needless to say, traditional media is under direct control by the authority (Leslie, 2002; Zheng, 2007; Howard, 2010). In some authoritarian states, the mainstream media is frequently operated and managed by the government itself (Stockmann, 2013). This gives amply room for the Internet to provide alternative information and alternative framing, leading to many critical views on government institutions from the citizens (Tang and Huhe, 2014). While democracies officially recognize free media, the agenda setting and news making of traditional media are often shaped by the society's political and economic elites (see Robinson, 1976; Hallin, 1984; Herman and Chomsky, 2010). By contrast, while the Internet may be subject to regulation in any country, it is far more difficult for the government to control the Internet in the same degree it does the traditional media (Howard, 2010; Morozov, 2011). Technical difficulties and the lacking of capacities and resources often prevent authoritarian institutions from completely controlling 
the Internet. Moreover, to its credit, online media tend to be judged more credible than their traditional versions (Johnson and Kaye, 1998).

To sum up, the Internet has become an essential space for developing new citizenship (Rimmerman, 2010; Huhe et al., 2018). It provides tools for concerned citizens, so that extensive discussion, negotiation, and consensus building can take place with relatively low cost. It also empowers by allowing citizens to bridge online and offline actions (Bohman, 2004; Bratton et al., 2005; Dahlgren, 2005; Groshek, 2009). Many see the Arab Spring as the manifestation of the Internet's empowering ability in organizing collective actions and political mobilization (Khondker, 2011; Hussain, and Howard, 2013; Wolfsfeld et al., 2013). In this and many other ways, the Internet has changed the political environment, transforming the patterns of state-society and government-citizens interactions (Bohman, 2004; Gil De Zúñiga et al., 2009). In short, we take the Internet as a major technology and space that foster the forming of critical citizenship, which includes a trust-eroding effect on government institutions.

Hypothesis 1: Globally, Internet use exerts a negative impact on citizens' trust in political institutions. (H1)

\subsection{Regime types and the Internet}

Although the Internet may reduce citizens' trust in government institutions, in a democratic vis-à-vis a non-democratic environment, this impact might differ to a great extent. Compared to democracies, authoritarian regimes appear to face more challenges when dealing with the Internet. The Internet dramatically reduces communication barriers for opposition groups and enhances potential protesters' ability to obtain and distribute information. It can efficiently transfer and publicize images and videos, which often add a dramatic effect to political communications. With that, collective action can be organized and mobilized much more effectively. This represents the first challenge to authoritarian regimes (Weber et al., 2003; Ruijgrok, 2017). Second, the Internet enables the public to interpret issues according to their preferences. This contributes to the formation of new frames in authoritarian regimes, where most information is strictly censored by the state (Tang and Huhe, 2014). It can, for example, alter web users' views about sanctioned information in a way that is unfavorable for the authoritarian state (Tang and Huhe, 2014: 563). Last but not least, the Internet facilitates civil activities by expanding the space and tools available for political participation and citizen mobilization (Yang, 2003, 2013; Lei, 2011; Wang and You, 2016). The enabling effect of the Internet is also stronger in an authoritarian environment compared to democracies. We formulate three ways in which regime types matter to the Internet's political impact.

\subsubsection{Regime change pressure}

In mature democracies, specific and diffuse political supports operate in different ways. Citizens might display low trust in political institutions or politicians but retain strong trust in the political system or its fundamental principles (Inglehart, 1999; Norris, 2002). In non-democracies, by contrast, the public's level of trust in political institutions has direct implications for citizens' support for the political regime. The erosion of citizens' trust in specific political institutions will lead to the whole political regime losing political legitimacy. With the extensive reach of the Internet and the attendant erosion in political trust, authoritarian regimes face heavy pressure at the regime level.

\subsubsection{Online-offline linkages}

Many analyses have shown the interaction between online activities and offline political participation such as petitions and demonstrations (see, e.g., Xenos and Moy, 2007; Gibson and Cantijoch, 2013; Oser et al., 2013). As a communication tool and part of the public space, in democracies, the Internet can effectively complement formally institutionalized ways of political participation. In fact, in democracies, online behaviors may produce social capital and trust (Shah et al., 2001). 
Social media activities were found to be associated with social trust, civic engagement, and political participation in the USA (Valenzuela et al., 2009). In the UK, the Internet helps convert those passive toward conventional or offline forms of political participation into active participants. Internet use could produce more active engagement with politics online, including contact with political parties, charities, and mainstream news services (Gibson et al., 2005: 577). In short, institutionalized forms of political participation appear to enable democratic regimes to harness the expansion of the Internet.

By contrast, Ruijgrok (2017) found that the use of the Internet in authoritarian regimes greatly facilitate protests. Unlike democracies, authoritarian regimes lack or purposely constrain institutional ways to 'absorb' the newly acquired expressive and participatory demands of its citizens when the Internet expands. Thus, in non-democracies, the Internet could become a means for collective action and poses a challenge to authoritarian regimes (Zheng and Wu, 2005; Shirky, 2011).

\subsubsection{Demands for regime opening}

By lowering information costs, the Internet can bring attitudinal changes by exposing citizens to alternative sources of information (Breuer and Groshek, 2014; Tang and Huhe, 2014; Ruijgrok, 2017). Specifically, Internet use was found to be associated with greater citizen commitment to democratic norms (Nisbet et al., 2012) - many democratically oriented citizens are created as they engage in the Internet age (Huhe et al., 2018). Individuals who use government websites also tend to demand greater openness, transparency, and responsiveness from the authorities (Welch et al., 2005). Such raised expectations of government openness and transparency are often harder to meet in authoritarian regimes and are therefore likely to reduce citizens' trust in political institutions and the regime. With a stronger commitment to democratic norms and embracing democratic values, citizens in closed regimes naturally aspire for political changes, and reject the incumbent regime (Huhe et al., 2018).

To sum up, comparing the two regime types, authoritarian regimes have very different state-society relations compared to democratic ones. As such, the rise of the Internet puts even more pressure on authoritarian regimes to maintain political legitimacy and deny or stall regime opening. If the arrival of the Internet is seen as an external shock, a democratic system appears much more capable of absorbing the shock - due to its inherent ability to link citizens into the political/governmental processes. Conversely, an authoritarian system is poorly prepared for it and will suffer more severe challenges brought about by the Internet.

The above discussion leads to a second hypothesis that we intend to test:

Hypothesis 2: In regimes with a lower degree of democracy, the Internet has a stronger depressing effect on citizens' trust in political institutions.

\subsection{The expression linkage in democracies}

The above discussion already hinted on what makes an authoritarian regime less able to weather the expansion of the Internet. Authoritarian regimes assiduously restrict free political expression, and institutionalized political participation such as elections are limited in scope and degree. Some authoritarian regimes of today run elections, but they are generally of low quality or are for powerless rubber-stamp institutions (Gandhi and Lust-Okar, 2009). Media freedom and the freedom of speech, furthermore, are strictly controlled, including in places such as Singapore where the freedom of speech exists nominally (Rodan, 2003, 2004). Extra-institutional or unconventional forms of political expression, such as petitions and demonstrations, are either banned outright or strictly limited. Public discontent is more likely to build up due to a lack of substantial ways of expression, leading to (potential) distrust in various political institutions. Democracies, on the contrary, provide formal institutions for representation and political expression. Moreover, extra-institutional forms of political expression, especially the opportunity to join petitions, demonstrations, and strikes, would more likely reveal public discontent and facilitate state-society communication. 
Many studies point to the link between online and offline activism when the Internet plays a political role. This linkage, as we argue, appears to explain the different effect that the Internet has on political trust in democracies vis-à-vis non-democracies. With various forms of political expression and participation, a democracy can dissipate the trust-eroding effect of the Internet more efficiently than a non-democracy. This linkage also allows the government to gauge public sentiment and understand public demands more effectively, leading to an improvement in policymaking and boosting public trust in government institutions. Citizens under authoritarian rule, however, are deprived of this online-offline connection, and the regime loses this positive feedback mechanism between citizen appeals and government responses. Furthermore, censorship and Internet control hinder citizens from relying on the Internet for deliberation, consensus making, and organizing collective action in their countries (King et al., 2017). Internet use in an authoritarian environment, therefore, would fail to generate positive gains that foster citizen-government trust.

Therefore, we hypothesize that free political expression in a democratic system provides a moderating effect on the relationship between the Internet and political (dis)trust. Due to the existence of legitimate expression and political participation, we suggest that in democracies, the Internet's adverse effect on political trust is likely to be less severe. We test the underlying mechanisms with the following hypothesis:

Hypothesis 3: Political expression has a moderating effect on the Internet's impact on political trust.

\section{Methodology}

\subsection{Data}

On the micro-level, we mainly use the latest wave of the WVS to test our hypotheses. We also input country-level variables from two data sources - socioeconomic indicators from the World Bank and the degree of democracy and regime type information from the Freedom House. The latest (sixth) wave of the WVS was conducted from 2010 to 2014, covering 52 societies and sampling over 75,000 people. Missing variables lead us to retain 44 societies in our study, and the full list is provided in Appendix A. Based on the Freedom House Index (FDI), our sample includes 19 'Free' (1-2.5), 12 'Partially Free' (3-5), and 11 'Not Free' (5.5-7) countries. Countries included in our dataset range from the most underdeveloped such as Rwanda to those with the highest gross domestic product (GDP) per capita in Western Europe, North America, and Oceania.

\subsection{Dependent variable}

The WVS measures respondents' trust in a range of political institutions. We selected trust in seven main political institutions for our analysis - the central government, the police, the armed forces, the courts, political parties, the parliament, and the civil service. We recoded these answers into a fourpoint scale ranging from none at all to a great deal of trust. Subsequently, we averaged the trust scores in all seven institutions to form a continuous dependent variable, Institutional Trust, which serves as our dependent variable. ${ }^{1}$

\subsection{Independent variables}

\subsubsection{Internet usage.}

The key independent variable for our study concerns the intensity of citizens' online activities. An Internet usage variable is coded into a five-point scale, ranging from never to daily.

\footnotetext{
${ }^{1}$ The trust scores in the seven institutions have a high Cronbach's $\alpha(0.870)$, thereby indicating a high internal consistency.
} 


\subsubsection{Democracy score.}

To test the moderating effect of democracy, we use the Freedom House score to measure the degree of democracy at the country level. Specifically, we recoded a country's original FH score into a continuous variable ranging from one to 12 . Higher scores indicate higher levels of democracy. ${ }^{2}$

\subsubsection{Political expression at the individual and country levels}

Institutional forms of expression, such as voting and contacting government officials and politicians, are not well-measured in the WVS. But one WVS strength allows us to test the moderating effect of political expression on the Internet's impact on political trust - this cross-national survey includes a set of questions recording the respondent's attitudes and/or behaviors in terms of extra-institutional forms of expression. These questions record whether one has, might, or would never sign a petition, participate in a boycott, attend a peaceful demonstration, or join a strike. We therefore rely on this battery to construct a variable for each type of extra-institutional forms of political expression.

At the individual level, we have treated each type of expressional activities as nominal variables. For petition, boycott, demonstration, and strike, those who registered 'have done' (HD) and 'might do' (MD) are both coded as ' 1 ', compared to those who registered 'would never do' (WND, coded as ' 0 ') in the dataset. We also use the average score of the four forms of participation as an ovall measure of an individual's political expression.

In addition, we have operationalized the degree of institutionalization that these forms of political expression have at the country level. For all four types of political expression, those who registered have done, might do, or would never do represent the mobilized, the potentially mobilized, and the not-at-all-mobilized, respectively. Using the formula below, a Country Expression Index for each type of expression measures the institutional structure of non-institutional political participation. Put another way, the relative proportion of these three categories of people forms a legitimate space for non-institutional political expression nationwide. By taking the average of the four scores, we can obtain an overall expression index for each country. In actual fact, various modes of noninstitutional political expression represent the voice of the people and are essential channels for participation in contemporary democracies (Norris et al., 2005).

Country Expression Index (for Petition, Boycott, Demonstration, Strike, and Average)

$$
=\frac{\text { numbers of have done }}{\text { numbers of might do }} / \text { numbers of would never do }
$$

\subsubsection{Interaction terms}

To test our hypotheses, we created one interaction term between Internet Usage and Democracy Score, and one set of interaction terms between Internet Usage and the country-level expression index for the various types of expressional activities (petition, boycott, demonstration, and strike) as well as the average index of all four expressional types.

\subsection{Control variables}

At the country level, we controlled for GDP per capita, Internet penetration, and mobile phone penetration. We control logarithmic GDP per capita for economic development, and Internet penetration and mobile phone penetration are measured by the number of users per 100 people in the country. At the individual level, we controlled for educational attainment and financial satisfaction since both have been suggested to be related to the formation of critical citizenship (Norris, 2011). We also controlled for a person's materialist/post-materialist disposition, categorizing each person as a materialist (Coded as ' 0 '), a post-materialist (Coded as ' 2 '), or as mixed (Coded as ' 1 '). Theories of social capital suggest

\footnotetext{
${ }^{2}$ The Freedom House original $1-7$ scale $(1,1.5,2,2.5, \ldots, 7$ are recoded into a $1-12$ scale: $1,2,3,4, \ldots, 12$.
} 
that high levels of interpersonal trust could provide a social foundation for political trust. Therefore, we accounted for the effects of social capital on political trust by including interpersonal trust as a variable. (For all detailed survey questions and recoding, see Appendix B.)

Lastly, we included political interest and the consumption of traditional media for theories of political learning (see Bratton et al., 2005). For the latter indicator, we classified newspapers, print magazines, television news, and radio news as traditional media. We then averaged each respondent's frequency of consuming these four forms of media as his/her intensity for traditional media use. ${ }^{3}$ Two demographic characteristics, age and gender, are also controlled.

Table 1 reports descriptive statistics of all the variables used.

\subsection{Empirical strategy}

We plan three steps to execute our analysis. First, we use multilevel models to examine potential interactive effects between individual Internet use and the degree of democracy at the country level, which enables us to examine whether the effect of Internet use on political trust differs across countries with different degrees of democracy.

In the second stage, we test whether the political expression in a democratic political environment can mitigate the downward pressure of Internet use on the public's trust in political institutions. A positive correlation exists between country-level political expression and degree of democracy. As a result, multilevel models can measure the potential interactive effects between individual Internet use and country-level political expression. By doing this, we can verify whether the variation in the trust-eroding effect of the Internet is due to regime types or different forms of political expression in countries with varying degrees of democracy.

After these analyses, we will conduct robustness checks with entropy balancing, whereby the reweighted data satisfy a set of specified moment conditions. Entropy balancing creates a treatment group and a control group, allowing us to estimate the average effect of Internet use on political trust. This approach also avoids imputing data for missing values in the sample (Hainmueller, 2011; Hainmueller and $\mathrm{Xu}, 2013$ ).

\section{Findings}

\subsection{Country-level effects}

Before testing the interactive effects between individual Internet use and regime type, we report OLS results for the effect of individual-level factors on political trust around the world (see Table 2). As expected (H1), whether or not we control country fixed-effect, Internet use exerts a negative and highly significant effect on political trust. Besides, the results also echo existing findings regarding political trust globally, that is, younger, more educated males are more likely to distrust their political institutions. The same applies to those less satisfied with their financial situation and those that harbor lower interpersonal trust and stronger post-materialist values.

We now include country-level variables and fix a series of multilevel models - more specifically, multilevel random coefficient models with cross-level interactions (Luke, 2004). As shown in Table 3, the null model (Model 1) shows that country-level factors can explain a significant portion of the variation - more than $17 \%$ of the variation in institutional trust is attributable to country-level factors $(\mathrm{ICC}=0.172){ }^{4}$

In Models 2 and 3 in Table 3, except individual-level control variables, we add our key explanatory variables, the interaction between a country's degree of democracy and individual Internet use, and other country-level control variables, such as the degree of economic development (GDP per capita),

\footnotetext{
${ }^{3}$ The Cronbach's $\alpha$ of these four types of media use is 0.751 , indicating high internal consistency for these variables.

${ }^{4} \mathrm{With}$ little significant change, Table 3 omits to report the regression efficiencies of individual-level control variables such as age, gender, financial satisfaction, and post-materialism, and of course, results are available upon request.
} 
Table 1. Descriptive statistics of variables

\begin{tabular}{|c|c|c|c|c|c|}
\hline \multicolumn{6}{|c|}{ Categorical variables (individual level) } \\
\hline Variable & $N$ & $\%$ & Variable & $N$ & $\%$ \\
\hline Gender & & & Boycott & & \\
\hline Male & 31,707 & 47.80 & WND & 43,128 & 68.53 \\
\hline \multirow[t]{2}{*}{ Female } & 34,622 & 52.20 & MD & 16,034 & 25.48 \\
\hline & & & $\mathrm{HD}$ & 3,775 & 6.00 \\
\hline Education level & & & Demonst & & \\
\hline Low & 15,915 & 24.22 & WND & 35,326 & 55.59 \\
\hline Moderate & 33,365 & 50.77 & MD & 20,275 & 31.91 \\
\hline High & 16,434 & 25.01 & $\mathrm{HD}$ & 7,944 & 12.50 \\
\hline Petition & & & Strike & & \\
\hline WND & 33,062 & 52.31 & WND & 41,417 & 65.72 \\
\hline MD & 17,304 & 27.38 & MD & 16,271 & 25.82 \\
\hline $\mathrm{HD}$ & 12,835 & 20.31 & $\mathrm{HD}$ & 5,328 & 8.45 \\
\hline
\end{tabular}

Continuous variables

\begin{tabular}{|c|c|c|c|c|c|c|}
\hline Variable & $N$ & Mean & Std. & Min & Max & Range \\
\hline \multicolumn{7}{|l|}{ Individual level } \\
\hline Institutional trust & 57,489 & 2.44 & 0.67 & 1 & 4 & 3 \\
\hline Age & 66,324 & 42.58 & 16.82 & 17 & 99 & 82 \\
\hline Household financial satisfaction & 65,899 & 5.92 & 2.44 & 1 & 10 & 9 \\
\hline Political interest & 65,632 & 2.34 & 0.96 & 1 & 4 & 3 \\
\hline Interpersonal trust & 64,582 & 0.25 & 0.43 & 0 & 1 & 1 \\
\hline Post-materialism & 63,585 & 0.71 & 0.61 & 0 & 2 & 2 \\
\hline Internet usage & 63,076 & 2.68 & 1.76 & 1 & 5 & 4 \\
\hline Traditional media usage & 62,814 & 3.36 & 0.97 & 1 & 5 & 4 \\
\hline \multicolumn{7}{|l|}{ Country level } \\
\hline Ln (GDP Per capita) & 44 & 1.50 & 1.70 & 0.06 & 6.05 & 5.99 \\
\hline Internet penetration & 44 & 42.53 & 25.16 & 4.87 & 92.01 & 87.14 \\
\hline Mobile phone penetration & 44 & 101.25 & 26.30 & 40.77 & 154.83 & 114.06 \\
\hline Democracy score & 44 & 7.56 & 3.72 & 1 & 12 & 11 \\
\hline Expression index: petition & 44 & 1.67 & 0.42 & 1.06 & 2.81 & 1.75 \\
\hline Expression index: boycott & 44 & 1.37 & 0.22 & 1.05 & 1.95 & 0.9 \\
\hline Expression index: demonstration & 44 & 1.56 & 0.22 & 1.11 & 1.96 & 0.85 \\
\hline Expression index: strike & 44 & 1.43 & 0.24 & 1.05 & 2.05 & 1 \\
\hline Average expression index & 44 & 1.50 & 0.25 & 1.09 & 2.11 & 1.02 \\
\hline
\end{tabular}

Note: 1. For variables petition, boycott, demonstration, and strike, WND: would never do; MD: might do; HD: have done. 2. As for variables of the country level, since the data about many countries and regions of 6th WVS is collected during from 2010 to 2012 , we use mean of corresponding variables (GDP per capita, Internet penetration, mobile phone penetration, and degree of democracy) from 2010 to 2012.

Internet penetration rate, and mobile phone penetration. The interaction term generates a significant and positive coefficient, which indicates that a democratic environment ameliorates the trust-eroding effect of the Internet. As Figure 1 illustrates, as the degree of democracy increases, the negative effect of Internet use on political trust gradually decreases. In fact, this negative effect becomes non-significant in countries with the highest level of democracy - in countries with a democracy score of 11 or higher, this negative effect stops to be significant at 0.05 level. In other words, while Internet use tends to generate people's distrust in political institutions, a democratic environment can significantly ameliorate this effect, which confirms our second hypothesis (H2).

\subsection{Internet ecologies in democracies and non-democracies}

We also suggest the space of political expression as the factor that mitigates the trust-eroding effect of the Internet. We now employ regression models to show that political expression forms the key to understanding the different political ecologies of the democracies and non-democracies. In Table 4, Models 1-8, respectively, examine the interaction effects between Internet use and each type of political expression, that is, petition, boycott, demonstration, strike, and an overall degree or space of 
Table 2. Internet use and institutional trust: a global trend

\begin{tabular}{|c|c|c|}
\hline & (1) & (2) \\
\hline Internet usage & $\begin{array}{c}-0.017^{\star \star \star} \\
(0.002)\end{array}$ & $\begin{array}{c}-0.012^{\star \star \star} \\
(0.002)\end{array}$ \\
\hline Age & $\begin{array}{l}0.001^{* * *} \\
(0.000)\end{array}$ & $\begin{array}{c}0.000^{\star} \\
(0.000)\end{array}$ \\
\hline Gender & $\begin{array}{c}-0.028^{\star \star \star} \\
(0.006)\end{array}$ & $\begin{array}{c}-0.035^{\star \star \star} \\
(0.005)\end{array}$ \\
\hline Household financial satisfaction & $\begin{array}{l}0.029^{\star \star *} \\
(0.001)\end{array}$ & $\begin{array}{l}0.028^{\star \star \star} \\
(0.001)\end{array}$ \\
\hline Interpersonal trust & $\begin{array}{l}0.205^{\star \star \star} \\
(0.007)\end{array}$ & $\begin{array}{l}0.153^{\star \star \star} \\
(0.007)\end{array}$ \\
\hline Political interest & $\begin{array}{l}0.124^{\star \star *} \\
(0.003)\end{array}$ & $\begin{array}{l}0.092^{* \star *} \\
(0.003)\end{array}$ \\
\hline Traditional media usage & $\begin{array}{l}0.056^{\star \star \star} \\
(0.003)\end{array}$ & $\begin{array}{l}0.069^{\star \star \star} \\
(0.003)\end{array}$ \\
\hline Post-materialism & $\begin{array}{c}-0.086^{* * *} \\
(0.005)\end{array}$ & $\begin{array}{c}-0.047^{\star * \star} \\
(0.005)\end{array}$ \\
\hline Political expression & $\begin{array}{c}-0.078^{\star \star *} \\
(0.006)\end{array}$ & $\begin{array}{c}-0.033^{\star * \star} \\
(0.006)\end{array}$ \\
\hline Educational level: moderate & $\begin{array}{c}-0.073^{\star \star \star} \\
(0.008)\end{array}$ & $\begin{array}{c}-0.044^{\star \star \star} \\
(0.008)\end{array}$ \\
\hline Education level: high & $\begin{array}{c}-0.101^{\star \star \star} \\
(0.010)\end{array}$ & $\begin{array}{c}-0.067^{\star \star \star} \\
(0.010)\end{array}$ \\
\hline Constant & $\begin{array}{l}2.088^{\star \star \star} \\
(0.016)\end{array}$ & $\begin{array}{l}1.890^{\star \star \star} \\
(0.031)\end{array}$ \\
\hline Country effect & No & Yes \\
\hline$N$ & 48,517 & 48,517 \\
\hline$R^{2}$ & 0.077 & 0.227 \\
\hline
\end{tabular}

Note: 1 . Robust standard errors in parentheses, and statistical significance reported as: ${ }^{\star} P<0.1,{ }^{\star \star} P<0.05$, ${ }^{\star \star \star} P<0.01$. 2 . For the education level, the reference group is low. 3. Political expression is the individual average value of petition, boycott, demonstration, and strike.

Table 3. Internet usage and institutional trust in different political regimes: multilevel models

\begin{tabular}{|c|c|c|c|}
\hline & $(1)$ & $(2)$ & (3) \\
\hline \multicolumn{4}{|l|}{ Individual level } \\
\hline Internet usage & & $\begin{array}{c}-0.012^{\star \star \star} \\
(0.002)\end{array}$ & $\begin{array}{c}-0.028^{\star \star \star} \\
(0.004)\end{array}$ \\
\hline \multicolumn{4}{|l|}{ Interaction terms } \\
\hline Internet usage $\times$ democracy score & & & $\begin{array}{l}0.002^{\star \star \star} \\
(0.000)\end{array}$ \\
\hline \multicolumn{4}{|l|}{ Country level } \\
\hline Ln (GDP per capita) & & $\begin{array}{c}-0.063 \\
(0.070)\end{array}$ & $\begin{array}{c}-0.062 \\
(0.070)\end{array}$ \\
\hline Internet penetration rate & & $\begin{array}{c}0.010 \\
(0.007)\end{array}$ & $\begin{array}{c}0.009 \\
(0.007)\end{array}$ \\
\hline Mobile phone penetration rate & & $\begin{array}{c}0.000 \\
(0.002)\end{array}$ & $\begin{array}{c}0.000 \\
(0.002)\end{array}$ \\
\hline Democracy score & & $\begin{array}{c}-0.018^{\star \star} \\
(0.008)\end{array}$ & $\begin{array}{c}-0.022^{\star \star \star} \\
(0.008)\end{array}$ \\
\hline Constant & $\begin{array}{l}2.404^{\star \star \star} \\
(0.042)\end{array}$ & $\begin{array}{l}2.492^{\star \star \star} \\
(0.494)\end{array}$ & $\begin{array}{l}2.520^{\star \star \star} \\
(0.494)\end{array}$ \\
\hline Individual-level control variables & No & Yes & Yes \\
\hline$F$ value (Wald statistic) & & $3,024.2^{\star \star \star}$ & $3,048.3^{\star \star \star}$ \\
\hline ICC & 0.172 & 0.101 & 0.106 \\
\hline $\mathrm{BIC} / d f$ & $35,481.8$ & $5,399.2$ & $5,080.9$ \\
\hline$N$ & 57,489 & 48,517 & 48,517 \\
\hline No. of country level & 44 & 44 & 44 \\
\hline
\end{tabular}

Note: 1. Robust standard errors in parentheses, and statistical significance reported as: ${ }^{\star} P<0.1,{ }^{\star \star} P<0.05,{ }^{\star \star \star} P<0.01$. 


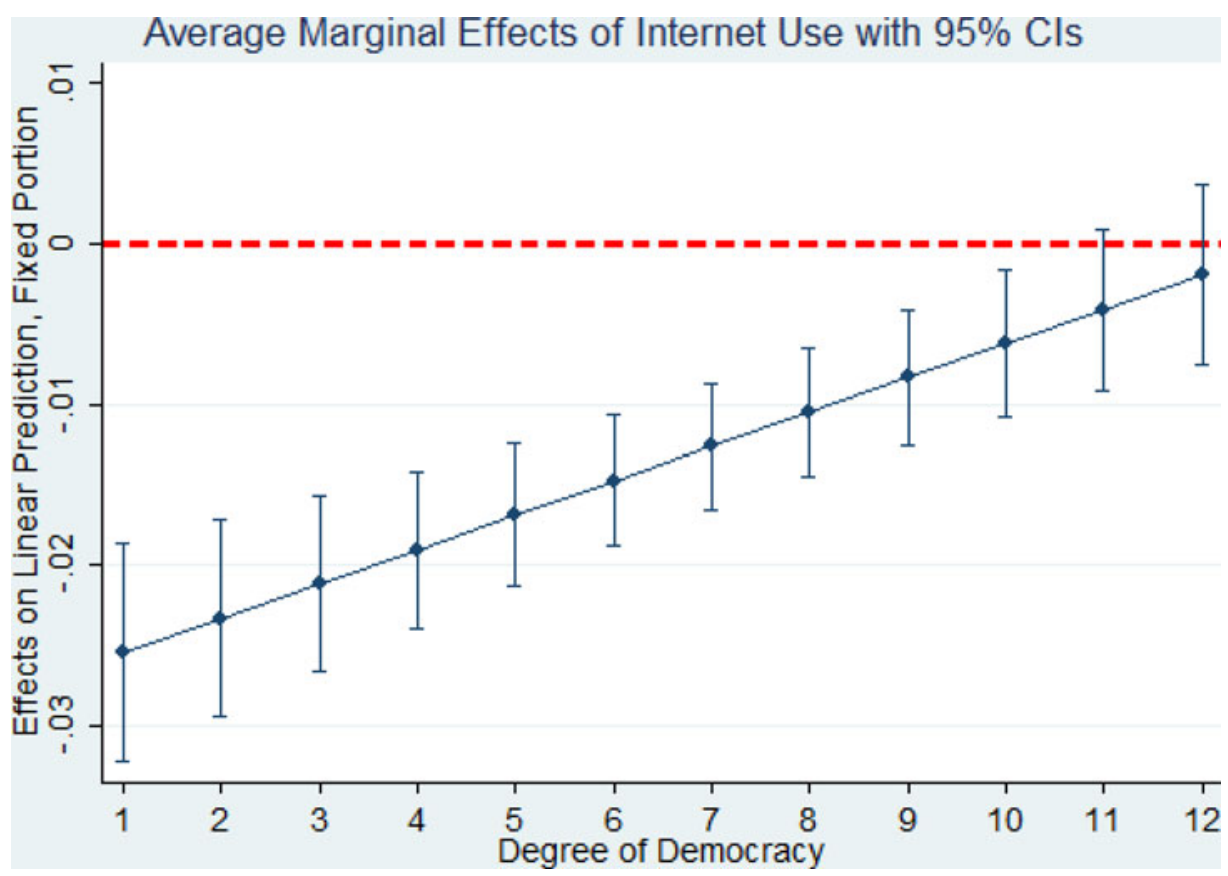

Figure 1. Average effect of Internet use with different democracy scores. Note: Based on Model 3 in Table 3.

expression. These models show that countries with less institutionalized forms of political expression suffer a severer effect of Internet use on institutional trust. Among them, the two more confrontational forms of political expression, that is, strikes and demonstrations, have the largest ameliorating effect on the Internet's impact on political trust. Models 9 and 10 also test this mechanism using the average expression index, showing consistent results.

Such an ameliorating role of political expression is shown in Figure 2, based on Model 10 in Table $4 .^{5}$ As it shows, with the increase of the average expression index, the negative effect of the Internet use on political trust gradually decreases. Similar to what is shown in Figure 1, in countries with the most liberal and active political expression, Internet use stops to have a significant effect on political trust.

As discussed above, democracies provide the space for political expression, which is almost missing in non-democratic regimes. The availability of unconventional forms of political expression, especially the opportunity to join petitions, demonstrations, and strikes, enables the public to channel their discontent and facilitates society-state communication. By contrast, authoritarian regimes hold a natural vigilance against various forms of political expression and social mobilization in general. Most of these forms of expression and mobilization are either outlawed outright, strictly suppressed, or closely managed in authoritarian regimes, thereby leaving little space for public expression.

Therefore, as expected in $\mathrm{H} 3$, these findings indicate that in regimes with more space for political expression, the trust-eroding effect of Internet use on political institutions appears less severe. The availability of and the ability to engage in various forms of political expression are key to understanding differences in the 'shock' that the Internet inflicts on democracies vis-à-vis non-democracies - with legalized means of political expression made available to the public, democracies are better able to absorb such a shock. Expression and political participation, in our research design, showcase a key mechanism in the working of Internet-related politics that separates democracies from non-democracies.

\footnotetext{
${ }^{5}$ For the similar interaction effects of different unconventional forms of political expression, see Appendix C.
} 
Table 4. Political expression and the Internet's impact on institutional trust

\begin{tabular}{|c|c|c|c|c|c|c|c|c|c|c|}
\hline & (1) & (2) & (3) & (4) & (5) & (6) & (7) & (8) & (9) & (10) \\
\hline Internet usage & $\begin{array}{l}-0.012^{\star \star \star} \\
(0.002)\end{array}$ & $\begin{array}{l}-0.044^{\star \star \star} \\
(0.007)\end{array}$ & $\begin{array}{l}-0.012^{\star \star \star} \\
(0.002)\end{array}$ & $\begin{array}{l}-0.038^{\star \star \star} \\
(0.011)\end{array}$ & $\begin{array}{l}-0.012^{\star \star \star} \\
(0.002)\end{array}$ & $\begin{array}{l}-0.086^{\star \star \star} \\
(0.012)\end{array}$ & $\begin{array}{l}-0.012^{\star \star \star} \\
(0.002)\end{array}$ & $\begin{array}{l}-0.078^{\star \star \star} \\
(0.010)\end{array}$ & $\begin{array}{l}-0.012^{\star \star \star} \\
(0.002)\end{array}$ & $\begin{array}{l}-0.066^{\star * \star} \\
(0.011)\end{array}$ \\
\hline \multirow[t]{2}{*}{ Interaction term } & \multicolumn{2}{|c|}{$\begin{array}{l}\text { Internet usage } x \\
\text { country petition index }\end{array}$} & \multicolumn{2}{|c|}{$\begin{array}{c}\text { Internet usage } x \\
\text { country boycott index }\end{array}$} & \multicolumn{2}{|c|}{$\begin{array}{l}\text { Internet usage } x \\
\text { country demonstration } \\
\text { index }\end{array}$} & \multicolumn{2}{|c|}{$\begin{array}{l}\text { Internet usage } \times \\
\text { country strike index }\end{array}$} & \multicolumn{2}{|c|}{$\begin{array}{l}\text { Internet usage } x \\
\text { average country } \\
\text { expression Index }\end{array}$} \\
\hline & & $\begin{array}{l}0.019^{\star \star \star} \\
(0.004)\end{array}$ & & $\begin{array}{l}0.019^{\star \star} \\
(0.008)\end{array}$ & & $\begin{array}{l}0.048^{\star \star \star} \\
(0.008)\end{array}$ & & $\begin{array}{l}0.047^{\star \star \star} \\
(0.007)\end{array}$ & & $\begin{array}{l}0.037^{\star \star \star} \\
(0.007)\end{array}$ \\
\hline Country boycott index & & & $\begin{array}{c}0.102 \\
(0.272)\end{array}$ & $\begin{array}{c}0.042 \\
(0.272)\end{array}$ & & & & & & \\
\hline Country demonstration index & & & & & $\begin{array}{l}-0.683^{\star \star \star} \\
(0.240)\end{array}$ & $\begin{array}{l}-0.803^{\star \star \star} \\
(0.240)\end{array}$ & & & & \\
\hline Country strike index & & & & & & & $\begin{array}{r}-0.306^{\star} \\
(0.223)\end{array}$ & $\begin{array}{r}-0.434^{\star} \\
(0.223)\end{array}$ & & \\
\hline Country average expression index & & & & & & & & & $\begin{array}{c}-0.322 \\
(0.264)\end{array}$ & $\begin{array}{c}-0.437^{\star} \\
(0.263)\end{array}$ \\
\hline $\mathrm{BIC} / \mathrm{df}$ & $4,896.7$ & $4,638.4$ & $4,897.4$ & $4,636.1$ & $4,932.9$ & $4,671.9$ & $4,917.1$ & $4,656.6$ & $5,082.2$ & $4,799.0$ \\
\hline N & 49,631 & 49,631 & 49,551 & 49,551 & 49,953 & 49,953 & 49,693 & 49,693 & 48,517 & 48,517 \\
\hline No. of country level & 44 & 44 & 44 & 44 & 44 & 44 & 44 & 44 & 44 & 44 \\
\hline
\end{tabular}

Note: 1. Robust standard errors in parentheses, and statistical significance reported as: ${ }^{*} P<0.1,{ }^{* \star} P<0.05,{ }^{* \star *} P<0.01$. 


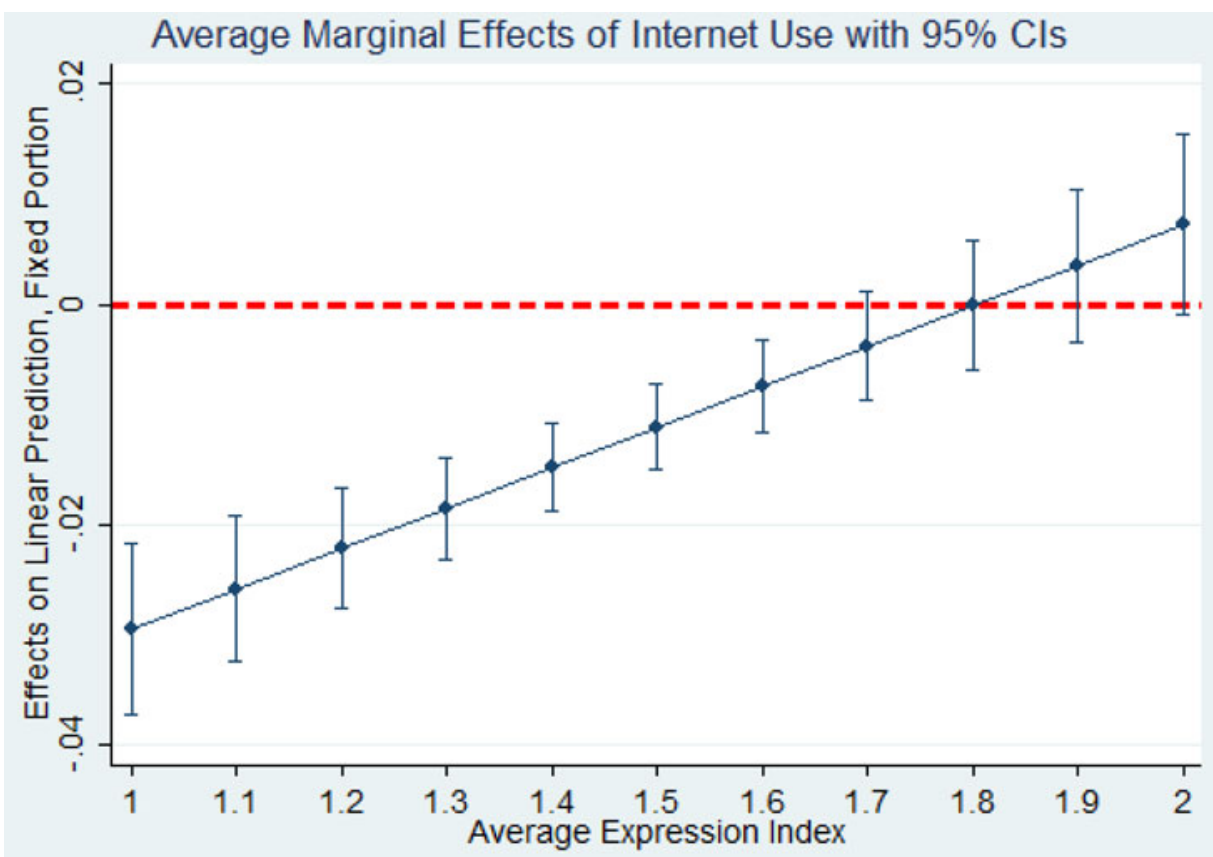

Figure 2. Average effect of Internet use with different country expression indices. Note: Based on Model 10 in Table 4.

\subsection{Robustness checks}

Since the measure on institutional trust is an average across seven groups of political institutions, we also use seemingly unrelated regression (SUR) to examine the effect on these types of political trust jointly, which are expected to improve estimation efficiency and reduce estimation bias caused by missing variables. ${ }^{6}$ The results (see Appendix D) show our findings in Table 2 are robust.

Regarding Internet use, we are faced with potential self-selection bias, which is similar to the effect of attending college on individual income (see Willis and Rosen, 1978; Heckman, 1990). People who use the Internet are likely to be younger, have a higher level of education, and are more satisfied with their financial situation. More importantly, Internet users are more willing to take part in petition signing, boycotts, demonstrations, and strikes (see Appendix E).

To address the potential bias which may compromise the reliability of our findings, we try to rebalance the two groups through entropy balancing. This method can match the individual characteristics between the never use group and the used group and turns the original sample into a quasi-experimental dataset. ${ }^{7}$ Next, with the dichotomous Internet Usage variable (the never use group as the reference group) and the entropy-weighted sample, we rerun multilevel models. The results also show democracies can moderate the downward pressure of Internet use on institutional trust, and the interaction terms between Internet use and various forms of political expression have significant positive coefficients (results are reported in Appendix G).

\section{Concluding remarks}

The Internet has become a significant part of every aspect of our lives - social, economic, and political. At the same time, democracies and non-democracies alike face ever-decreasing levels of public trust in

\footnotetext{
${ }^{6}$ For a detailed discussion about SUR, see Zellner (1962).

${ }^{7}$ For group difference between before weight and after weight, see Appendix F.
} 
their political institutions. The linkage between these two trends has aroused extensive attention from academic circles (e.g., Tang and Huhe, 2018). Globally, longitudinal surveys of peoples' online behavior on a global scale are hard to come by Nisbet et al. (2012: 260), making it difficult to uncover the mechanisms between Internet use and political attitudes or behavior that may operate across individual countries. The WVS, while a cross-sectional dataset, still makes it possible to examine the linkage between Internet use and global citizen politics. More importantly, our research design enables us to ascertain the vastly different effect of the Internet on politics in democratic and non-democratic systems. While Internet use appears to foster critical citizenship, a democratic environment can moderate its trust-eroding effect and improve citizen-government communication. By contrast, authoritarian regimes face a trust-eroding Internet dynamic that their rigid controls appear to exacerbate.

Our analysis points to the availability of various forms of political expression as the mechanism through which Internet use affects citizen-government interaction. Citizens' online behavior, on the one hand, and the government's reading of and responses to public sentiment, on the other, appear to be connected by public expression. By institutionalizing citizens' rights to expressive activities and political activism, democracies can harness the rising tide of critical citizens enabled by the Internet. In contrast, an open Internet coexists with a closed regime in most authoritarian states (Kalathil and Boas, 2010). With fears of citizen activism, authoritarian regimes are making the Internet a quake lake, in which growing public discontent threatens to explode sooner rather than later.

Some non-democracies in the world have started the development of e-participation (Åström et al., 2012). Some research shows that the newly acquired e-government capabilities boost the legitimacy of authoritarian regimes (Stier, 2015). In many cases, the Internet has empowered both the citizenry and the state (Zheng, 2007). Our findings provide decisive evidence regarding the authoritarian regime's uphill struggle against the demand for openness and expression in the Internet age. The democratizing effect of the Internet holds important promise. As Paul Krugman writes, 'we are heading for a world that is basically democratic, because you can't keep them down on the farm once they have Internet access' (Krugman, 1999: 49). For authoritarian regimes, they restrict their citizens' expression only to find that citizens empowered by the Internet become more determined to take further action.

Funding information. This research was supported by the Fundamental Research Funds for the Central Universities at Chongqing University (Grant NO. 2019GGXY03).

Supplementary material. The supplementary material for this article can be found at https://dataverse.harvard.edu/dataset. xhtml?persistentId=doi:10.7910/DVN/OMQMHS

\section{References}

Åström J, Karlsson M, Linde J and Pirannejad A (2012) Understanding the rise of e-participation in non-democracies: domestic and international factors. Government Information Quarterly 29, 142-150.

Bohman J (2004) Expanding dialogue: the Internet, the public sphere and prospects for transnational democracy. The Sociological Review 52, 131-155.

Bratton M, Mattes RB and Gyimah-Boadi E (2005) Public Opinion, Democracy, and Market Reform in Africa. Cambridge: Cambridge University Press.

Breuer A and Groshek J (2014) Online media and offline empowerment in post-rebellion Tunisia: an analysis of internet use during democratic transition. Journal of Information Technology and Politics 11, 25-44.

Cho Y (2014) Internet and democratic citizenship among the global mass publics: does internet use increase political support for democracy? Japanese Journal of Political Science 15, 661-682.

Dahlberg L (2001) The internet and democratic discourse: exploring the prospects of online deliberative forums extending the public sphere. Information, Communication \& Society 4, 615-633.

Dahlgren P (2005) The Internet, public spheres, and political communication: dispersion and deliberation. Political Communication 22, 147-162.

Diamond L (2008) The Spirit of Democracy: the Struggle to Build Free Societies Throughout the World. Basingstoke: Macmillan.

Dunleavy P, Margetts H, Bastow S and Tinkler J (2006) Digital Era Governance: IT Corporations, the State, and e-Government. Oxford: Oxford University Press.

Eltantawy N and Wiest JB (2011) The Arab spring| social media in the Egyptian revolution: reconsidering resource mobilization theory. International Journal of Communication 5, 1207-1224. 
Gandhi J and Lust-Okar E (2009) Elections under authoritarianism. Annual Review of Political Science 12, 403-422.

Gibson R and Cantijoch M (2013) Conceptualizing and measuring participation in the age of the internet: Is online political engagement really different to offline? The Journal of Politics 75, 701-716.

Gibson RK, Lusoli W and Ward S (2005) Online participation in the UK: testing a 'contextualised' model of internet effects. The British Journal of Politics \& International Relations 7, 561-583.

Gil De Zúñiga H, Puig-I-Abril E and Rojas H (2009) Weblogs, traditional sources online and political participation: an assessment of how the internet is changing the political environment. New Media and Society 11, 553-574.

Groshek J (2009) The democratic effects of the Internet, 1994-2003 a cross-national inquiry of 152 countries. International Communication Gazette 71, 115-136.

Hainmueller J (2011) Entropy balancing for causal effects: a multivariate reweighting method to produce balanced samples in observational studies. Political Analysis 20, 25-46.

Hainmueller J and Xu Y (2013) Ebalance: a Stata package for entropy balancing. Journal of Statistical Software, 54.

Hallin DC (1984) The media, the war in Vietnam, and political support: a critique of the thesis of an oppositional media. The Journal of Politics 46, 1-24.

Heckman JJ (1990) Selection bias and self-selection. In Eatwell J, Milgate M, and Newman P (eds) Econometrics. London: Palgrave Macmillan, pp. 201-224.

Herman ES and Chomsky N (2010) Manufacturing consent: The Political Economy of the Mass Media. New York: Random House.

Howard PN (2010) The Digital Origins of Dictatorship and Democracy: Information Technology and Political Islam. New York: Oxford University Press.

Howard PN and Hussain MM (2011) The role of digital media. Journal of Democracy 22, 35-36.

Huhe N, Tang M and Chen J (2018) Creating democratic citizens? The political effects of the Internet in China. Political Research Quarterly 71, 757-771.

Huntington SP (1991) The Third Wave: Democratization in the Late Twentieth Century. Norman: University of Oklahoma Press.

Hussain MM and Howard PN (2013) What best explains successful protest cascades? ICTs and the fuzzy causes of the Arab Spring. International Studies Review 15, 48-66.

Inglehart R (1997) Modernization and Postmodernization: Cultural, Economic, and Political Change in 43 Societies. Cambridge: Cambridge University Press.

Inglehart R (1999) Postmodernization erodes respect for authority, but increases support for democracy. In Norris P (ed.), Critical Citizens: Global Support for Democratic Governance. Oxford: Oxford University Press, pp. 236-256.

Inglehart $\mathbf{R}$ and Baker WE (2000) Modernization, cultural change, and the persistence of traditional values. American Sociological Review 65, 19-51.

Johnson TJ and Kaye B (1998) Crusing is believing? Comparing Internet and traditonal sources on media credibility measures. Journalism \& Mass Communication Quarterly 75, 325-340.

Kalathil S and Boas TC (2010) Open Networks, Closed Regimes: the Impact of the Internet on Authoritarian Rule. Washington, D.C: Carnegie Endowment.

Khondker HH (2011) Role of the new media in the Arab Spring. Globalizations 8, 675-679.

King G, Pan J and Robbert ME (2017) How the Chinese government fabricates social media posts for strategic distraction, not engaged argument. American Political Science Review 111, 484-501.

Krugman P (1999) Understanding globalization. Washington Monthly 31, 49-50.

Lei Y-W (2011) The political consequences of the rise of the Internet: political beliefs and practices of Chinese netizens. Political Communication 28, 291-322.

Leslie M (2002) The Internet and democratization. Media and Democracy in Africa, 107-128.

Luke DA (2004) Multilevel Modeling. Thousand Oaks, CA: Sage.

Morozov E (2011) Whither internet control? Journal of Democracy 22, 62-74.

Nisbet EC, Stoycheff E and Pearce KE (2012) Internet use and democratic demands: a multinational, multilevel model of Internet use and citizen attitudes about democracy. Journal of Communication 62, 249-265.

Nisbet M and Scheufele D (2004) Political talk as a catalyst for online citizenship. Journalism \& Mass Communication Quarterly, SAGE Publications 81, 877-896.

Norris P (1999) Critical Citizens: Global Support for Democratic Government: Global Support for Democratic Government. New York: Oxford University Press.

Norris P (2002) Democratic phoenix: Reinventing Political Activism. Cambridge: Cambridge University Press.

Norris P (2008) Driving Democracy: Do Power-sharing Institutions Work? Cambridge: Cambridge University Press.

Norris P (2011) Democratic Deficit: Critical Citizens Revisited. Cambridge: Cambridge University Press.

Norris P, Walgrave S and Van Aelst P (2005) Who demonstrates? Antistate rebels, conventional participants, or everyone? Comparative Politics, 37, 189-205.

Oser J, Hooghe M and Marien S (2013) Is online participation distinct from offline participation? A latent class analysis of participation types and their stratification. Political Research Quarterly 66, 91-101. 
Rimmerman CA (2010) The New Citizenship: Unconventional Politics, Activism, and Service. Boulder, CO: Westview Press. Robinson MJ (1976) Public affairs television and the growth of political malaise: the case of "The selling of the Pentagon". The American Political Science Review 70, 409-432.

Rodan G (2003) Embracing electronic media but suppressing civil society: authoritarian consolidation in Singapore. The Pacific Review 16, 503-524.

Rodan G (2004) Transparency and Authoritarian Rule in Southeast Asia: Singapore and Malaysia. London and New York: Routledge.

Ruijgrok K (2017) From the web to the streets: internet and protests under authoritarian regimes authoritarian regimes. Democratization 24, 498-520.

Shah DV, Kwak N and Holbert RL (2001) 'Connecting' and 'disconnecting' with civic life: patterns of internet use and the production of social capital. Political Communication 18, 141-162.

Shirky C (2011) The political power of social media: technology, the public sphere, and political change. Foreign Affairs $\mathbf{9 0}$ $28-41$.

Stier S (2015) Political determinants of E-government performance revisited: comparing democracies and autocracies. Government Information Quarterly 32, 270-278.

Stockmann D (2013) Media Commercialization and Authoritarian Rule in China. Cambridge: Cambridge University Press.

Tang $\mathbf{M}$ and Huhe $\mathbf{N}$ (2014) Alternative framing: the effect of the Internet on political support in authoritarian China. International Political Science Review 35, 559-576.

Tang $\mathbf{M}$ and Huhe $\mathbf{N}$ (2018) Parsing the Effect of the Internet on Regime Support in China. Government and Opposition, pp. 1-17. https://doi.org/10.1017/gov.2017.39.

Tucker JA (2007) Enough! Electoral fraud, collective action problems, and post-communist colored revolutions. Perspectives on Politics 5, 535-551.

Valenzuela S, Park N and Kee KF (2009) Is there social capital in a social network site? Facebook use and college student's life satisfaction, trust, and participation1. Journal of Computer-Mediated Communication 14, 875-901.

Wang Z and You Y (2016) The arrival of critical citizens: decline of political trust and shifting public priorities in China. International Review of Sociology 26, 105-124.

Weber LM, Loumakis A and Bergman J (2003) Who participates and why? An analysis of citizens on the Internet and the mass public. Social Science Computer Review 21, 26-42.

Welch EW, Hinnant CC and Moon MJ (2005) Linking citizen satisfaction with e-government and trust in government. Journal of Public Administration Research and Theory 15, 371-391.

Willis RJ and Rosen S (1978) Education and Self-Selection. Cambridge, Mass., USA: National Bureau of Economic Research Cambridge.

Wolfsfeld G, Segev E and Sheafer T (2013) Social media and the Arab Spring: politics comes first. The International Journal of Press/Politics 18, 115-137.

Xenos M and Moy P (2007) Direct and differential effects of the Internet on political and civic engagement. Journal of Communication 57, 704-718.

Yang G (2003) The co-evolution of the Internet and civil society in China. Asian Survey 43, 405-422.

Yang G (2013) The Power of the Internet in China: Citizen Activism Online. New York: Columbia University Press.

Zellner A (1962) An efficient method of estimating seemingly unrelated regressions and tests for aggregation bias. Journal of the American Statistical Association 57, 348-368.

Zheng Y (2007) Technological Empowerment: The Internet, State, and Society in China. Stanford, CA: Stanford University Press.

Zheng Y and Wu G (2005) Information technology, public space, and collective action in China. Comparative Political Studies 38, 507-536. 
Appendix A. Country sample in this study from the sixth wave of the World Values Surveys

\begin{tabular}{|c|c|c|c|c|c|c|c|c|c|}
\hline Country code & Country name & Survey year & Freedom house index & Observations & Country code & Country name & Survey year & Freedom house index & Observations \\
\hline 12 & Algeria & 2014 & 5.5 & 1,200 & 504 & Morocco & 2011 & 4.5 & 1,200 \\
\hline 31 & Azerbaijan & 2011 & 5.5 & 1,002 & 528 & Netherlands & 2012 & 1 & 1,902 \\
\hline 36 & Australia & 2012 & 1 & 1,477 & 554 & New Zealand & 2011 & 1 & 841 \\
\hline 51 & Armenia & 2011 & 5 & 1,100 & 566 & Nigeria & 2011 & 4.5 & 1,759 \\
\hline 152 & Chile & 2011 & 1 & 1,000 & 586 & Pakistan & 2012 & 4.5 & 1,200 \\
\hline 156 & China & 2012 & 6.5 & 2,300 & 604 & Peru & 2012 & 2.5 & 1,210 \\
\hline 170 & Colombia & 2012 & 3.5 & 1,512 & 608 & Philippines & 2012 & 3.5 & 1,200 \\
\hline 196 & Cyprus & 2011 & 1 & 1,000 & 616 & Poland & 2012 & 1 & 966 \\
\hline 218 & Ecuador & 2013 & 3 & 1,202 & 642 & Romania & 2012 & 2 & 1,503 \\
\hline 233 & Estonia & 2011 & 1 & 1,533 & 643 & Russia & 2011 & 5.5 & 2,500 \\
\hline 276 & Germany & 2013 & 1 & 2,046 & 646 & Rwanda & 2012 & 5.5 & 1,527 \\
\hline 288 & Ghana & 2011 & 1.5 & 1,552 & 724 & Spain & 2011 & 1 & 1,189 \\
\hline 356 & India & 2014 & 2.5 & 4,078 & 705 & Slovenia & 2011 & 1 & 1,069 \\
\hline 368 & Iraq & 2013 & 5.5 & 1,200 & 716 & Zimbabwe & 2011 & 6 & 1,499 \\
\hline 392 & Japan & 2010 & 1.5 & 2,443 & 752 & Sweden & 2011 & 1 & 1,206 \\
\hline 398 & Kazakhstan & 2011 & 5.5 & 1,502 & 780 & Trinidad and Tobago & 2010 & 2 & 999 \\
\hline 400 & Jordan & 2014 & 5.5 & 1,200 & 788 & Tunisia & 2013 & 5.5 & 1,205 \\
\hline 410 & South Korea & 2010 & 1.5 & 1,200 & 792 & Turkey & 2011 & 3 & 1,605 \\
\hline 417 & Kyrgyzstan & 2011 & 5.5 & 1,500 & 804 & Ukraine & 2011 & 3 & 1,500 \\
\hline 422 & Lebanon & 2013 & 4.5 & 1,200 & 840 & United States & 2011 & 1 & 2,232 \\
\hline 458 & Malaysia & 2011 & 4 & 1,300 & 858 & Uruguay & 2011 & 1 & 1,000 \\
\hline 484 & Mexico & 2012 & 3 & 2,000 & 887 & Yemen & 2013 & 6 & 1,000 \\
\hline
\end{tabular}




\section{Appendix B. Relevant survey questions and recoding}

\begin{tabular}{|c|c|c|}
\hline Variable & Survey question & Recoding \\
\hline Educational level & $\begin{array}{l}\text { What is the highest educational level that you } \\
\text { have attained? } \\
\text { 1: No formal education } \\
\text { 2: Incomplete primary school } \\
\text { 3: Complete primary school } \\
\text { 4: Incomplete secondary school: technical/ } \\
\text { vocational type } \\
\text { 5: Complete secondary school: technical/ } \\
\text { vocational type } \\
\text { 6: Incomplete secondary: university-preparatory } \\
\text { type } \\
\text { 7: Complete secondary: university-preparatory } \\
\text { type } \\
\text { 8: Some university-level education, without } \\
\text { degree } \\
\text { 9: University-level education, with degree }\end{array}$ & $\begin{array}{l}\text { Low: } 1-3 \\
\text { Moderate: } 4-6 \\
\text { High: } 7-9\end{array}$ \\
\hline Interpersonal trust & $\begin{array}{l}\text { Generally speaking, would you say that most } \\
\text { people can be trusted or that you need to be } \\
\text { very careful in dealing with people? } \\
\text { 1: Most people can be trusted } \\
\text { 2: Need to be very careful }\end{array}$ & $\begin{array}{l}0: \text { Need to be very careful } \\
1: \text { Most people can be trusted }\end{array}$ \\
\hline $\begin{array}{l}\text { Financial satisfaction } \\
\text { of household }\end{array}$ & $\begin{array}{l}\text { How satisfied are you with the financial situation } \\
\text { of your household? Scores between } 1 \text { and } 10 \text {, } \\
1 \text { represents Completely dissatisfied, } 10 \\
\text { represents completely satisfied }\end{array}$ & \\
\hline Interest in politics & $\begin{array}{l}\text { How interested would you say you are in politics? } \\
\text { 1: Very interested } \\
\text { 2: Somewhat interested } \\
\text { 3: Not very interested } \\
\text { 4: Not at all interested }\end{array}$ & $\begin{array}{l}\text { 1: Not at all interested } \\
\text { 2: Not very interested } \\
\text { 3: Somewhat interested } \\
\text { 4: Very interested }\end{array}$ \\
\hline Internet use & $\begin{array}{l}\text { For each of the following sources, please indicate } \\
\text { whether you use it to obtain information daily, } \\
\text { weekly, monthly, less than monthly or never } \\
\text { (Internet) } \\
\text { 1: Daily 2: Weekly 3: Monthly; 4: Less than } \\
\text { Monthly; 5: Never }\end{array}$ & $\begin{array}{l}\text { 1: Never; 2: Less than Monthly; 3: Monthly; 4: } \\
\text { Weekly; 5: Daily }\end{array}$ \\
\hline traditional media use & $\begin{array}{l}\text { For each of the following sources, please indicate } \\
\text { whether you use it to obtain information daily, } \\
\text { weekly, monthly, less than monthly or never } \\
\text { (Daily newspaper, Printed magazines, TV news } \\
\text { and Radio news) } \\
\text { 1: Daily; 2: Weekly; } 3 \text { : Monthly; 4: Less than } \\
\text { Monthly; 5: Never }\end{array}$ & $\begin{array}{l}\text { 1: Never; 2: Less than Monthly; 3: Monthly 4: } \\
\text { Weekly; 5: Never. We average Daily } \\
\text { newspaper, Printed magazines, TV news, } \\
\text { and Radio news as mean of traditional } \\
\text { media use }\end{array}$ \\
\hline Post-materialism & $\begin{array}{l}\text { Which would be the most important and the next } \\
\text { most important? } \\
\text { 1: Maintaining order in the nation } \\
\text { 2: Giving people more say in important } \\
\text { government decisions } \\
\text { 3: Fighting rising prices } \\
\text { 4: Protecting freedom of speech }\end{array}$ & $\begin{array}{l}\text { Materialism (0): } 1 \text { and } 3 \\
\text { Post-materialism (2): } 2 \text { and } 4 \\
\text { Mixed (1): others }\end{array}$ \\
\hline
\end{tabular}


Appendix C. Average marginal effect of Internet use with different unconventional forms of political expression
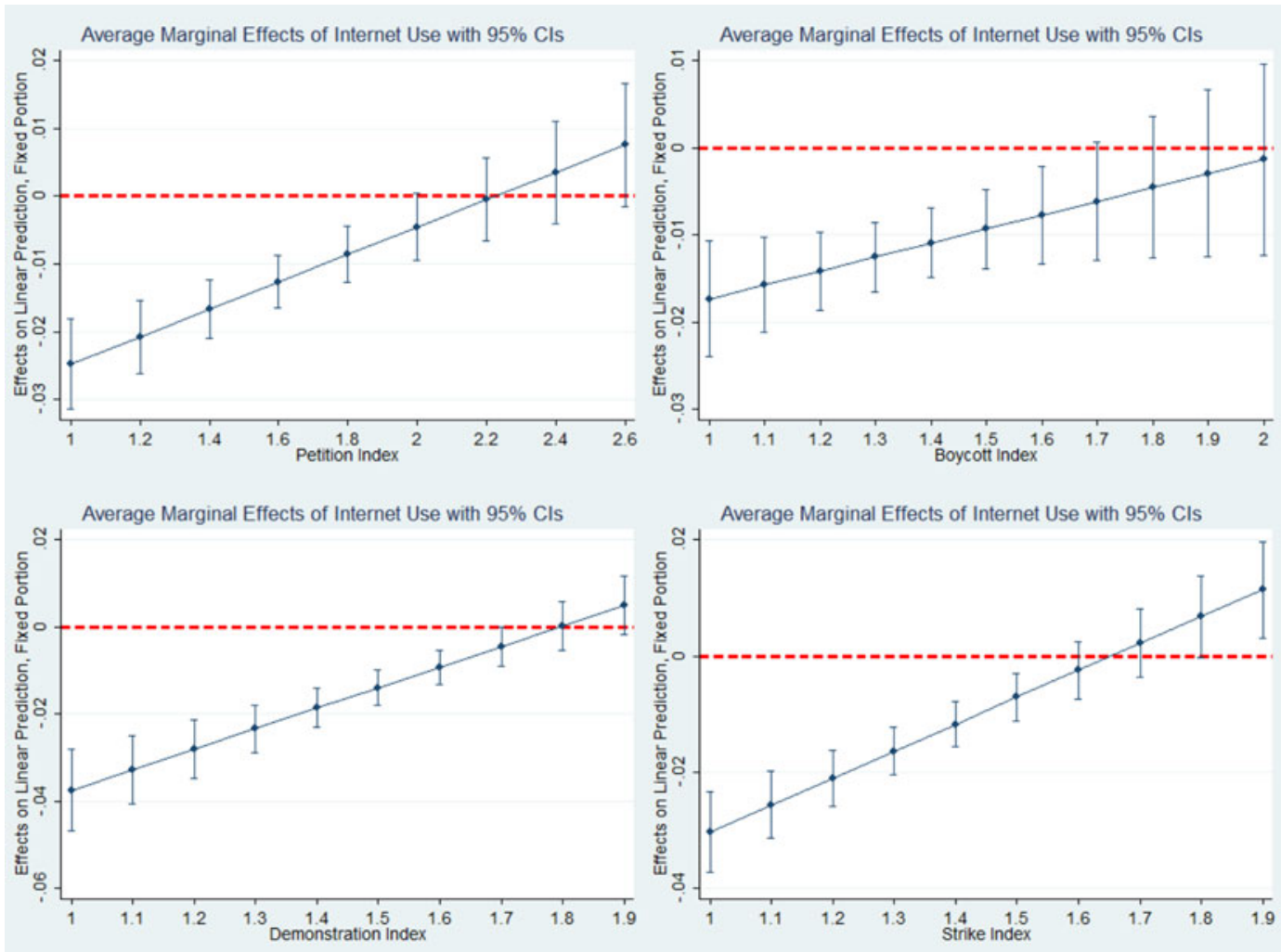

Note: The marginal effect is based on the models in Table 4. 


\section{Appendix D. The SUR model of the political trust in seven groups}

\begin{tabular}{|c|c|c|c|c|c|c|c|}
\hline & Army & Police & Courts & Central government & Parties & Parliament & Civil service \\
\hline \multirow[t]{2}{*}{ Internet usage } & $-0.017^{\star \star \star}$ & $-0.007^{\star \star \star}$ & $-0.009^{\star \star \star}$ & $-0.017^{\star \star \star}$ & $-0.016^{\star \star \star}$ & $-0.015^{\star \star \star}$ & $-0.010^{\star \star \star}$ \\
\hline & $(0.003)$ & $(0.003)$ & $(0.003)$ & $(0.003)$ & $(0.003)$ & $(0.003)$ & $(0.003)$ \\
\hline \multirow[t]{2}{*}{ Age } & $0.003^{\star \star \star}$ & $0.001^{\star \star \star}$ & $-0.001^{\star \star \star}$ & $0.001^{*}$ & -0.000 & -0.000 & 0.000 \\
\hline & $(0.000)$ & $(0.000)$ & $(0.000)$ & $(0.000)$ & $(0.000)$ & $(0.000)$ & $(0.000)$ \\
\hline \multirow[t]{2}{*}{ Gender } & $0.037^{\star \star \star}$ & $-0.065^{\star \star \star}$ & $-0.054^{\star \star \star}$ & $-0.053^{\star \star \star}$ & $-0.039^{\star \star \star}$ & $-0.027^{\star \star \star}$ & $-0.042^{\star \star \star}$ \\
\hline & $(0.008)$ & $(0.008)$ & $(0.008)$ & $(0.008)$ & $(0.007)$ & $(0.007)$ & $(0.007)$ \\
\hline \multirow[t]{2}{*}{ Household financial satisfaction } & $0.105^{\star \star \star}$ & $0.160^{\star \star \star}$ & $0.163^{\star \star \star}$ & $0.191^{\star \star \star}$ & $0.156^{\star \star \star}$ & $0.160^{\star \star \star}$ & $0.138^{\star \star \star}$ \\
\hline & $(0.010)$ & $(0.010)$ & $(0.010)$ & $(0.010)$ & $(0.009)$ & $(0.009)$ & $(0.009)$ \\
\hline \multirow[t]{2}{*}{ Interpersonal trust } & $0.021^{\star \star \star}$ & $0.028^{\star \star \star}$ & $0.031^{\star \star \star}$ & $0.034^{\star \star *}$ & $0.025^{\star \star \star}$ & $0.030^{\star \star \star}$ & $0.025^{\star \star \star}$ \\
\hline & $(0.002)$ & $(0.002)$ & $(0.002)$ & $(0.002)$ & $(0.002)$ & $(0.002)$ & $(0.002)$ \\
\hline \multirow{2}{*}{ Political interest } & $0.061^{\star \star \star}$ & $0.059^{\star \star \star}$ & $0.057^{\star \star \star}$ & $0.098^{\star \star \star}$ & $0.175^{\star \star \star}$ & $0.120^{\star \star \star}$ & $0.074^{\star \star \star}$ \\
\hline & $(0.004)$ & $(0.004)$ & $(0.004)$ & $(0.004)$ & $(0.004)$ & $(0.004)$ & (0.004) \\
\hline \multirow[t]{2}{*}{ Educational level: moderate } & -0.008 & $-0.055^{\star \star \star}$ & $-0.045^{\star \star \star}$ & $-0.047^{\star \star \star}$ & $-0.067^{\star \star \star}$ & $-0.061^{\star \star \star}$ & $-0.026^{\star \star}$ \\
\hline & $(0.011)$ & $(0.011)$ & $(0.011)$ & $(0.011)$ & $(0.010)$ & $(0.011)$ & $(0.011)$ \\
\hline \multirow[t]{2}{*}{ Education level: high } & $-0.065^{\star \star \star}$ & $-0.109^{\star \star \star}$ & $-0.065^{\star \star \star}$ & $-0.051^{\star \star \star}$ & $-0.109^{\star \star \star}$ & $-0.057^{\star \star \star}$ & -0.015 \\
\hline & (0.014) & $(0.014)$ & (0.014) & (0.014) & (0.013) & (0.013) & (0.013) \\
\hline \multirow[t]{2}{*}{ Traditional media usage } & $0.070^{\star \star \star}$ & $0.090^{\star \star \star}$ & $0.081^{\star \star \star}$ & $0.066^{\star \star \star}$ & $0.054^{\star \star \star}$ & $0.065^{\star \star \star}$ & $0.058^{\star \star \star}$ \\
\hline & $(0.005)$ & (0.005) & $(0.005)$ & $(0.005)$ & (0.004) & $(0.005)$ & (0.005) \\
\hline \multirow[t]{2}{*}{ Post-materialism } & $-0.071^{\star \star \star}$ & $-0.050^{\star \star \star}$ & $-0.050^{\star \star \star}$ & $-0.048^{\star \star \star}$ & $-0.029^{\star \star \star}$ & $-0.049^{\star \star \star}$ & $-0.036^{\star \star \star}$ \\
\hline & $(0.007)$ & $(0.007)$ & $(0.007)$ & $(0.007)$ & $(0.006)$ & $(0.006)$ & $(0.006)$ \\
\hline \multirow[t]{2}{*}{ Political expression } & $-0.020^{\star *}$ & $-0.057^{\star \star \star}$ & -0.005 & $-0.072^{\star \star \star}$ & $-0.035^{\star \star \star}$ & $-0.036^{\star \star \star}$ & -0.005 \\
\hline & $(0.008)$ & $(0.008)$ & $(0.008)$ & (0.008) & $(0.008)$ & (0.008) & $(0.008)$ \\
\hline \multirow[t]{2}{*}{ Constant } & $2.295^{\star \star \star}$ & $2.248^{\star \star \star}$ & $2.018^{\star \star \star}$ & $1.848^{\star \star \star}$ & $1.410^{\star \star \star}$ & $1.542^{\star \star \star}$ & $1.870^{\star \star \star}$ \\
\hline & $(0.044)$ & $(0.045)$ & $(0.045)$ & $(0.045)$ & $(0.041)$ & $(0.042)$ & $(0.042)$ \\
\hline Observations & 48,517 & 48,517 & 48,517 & 48,517 & 48,517 & 48,517 & 48,517 \\
\hline City-effect & Yes & Yes & Yes & Yes & Yes & Yes & Yes \\
\hline$R^{2}$ & 0.137 & 0.162 & 0.159 & 0.173 & 0.211 & 0.216 & 0.172 \\
\hline
\end{tabular}

Note: 1 . Standard errors in parentheses and ${ }^{\star \star \star} P<0.01,{ }^{\star \star} P<0.05,{ }^{\star} P<0.1 ; 2 . \operatorname{Pr}=0.000$. 
Appendix E.1. Difference in political expression (MD) by Internet usage.

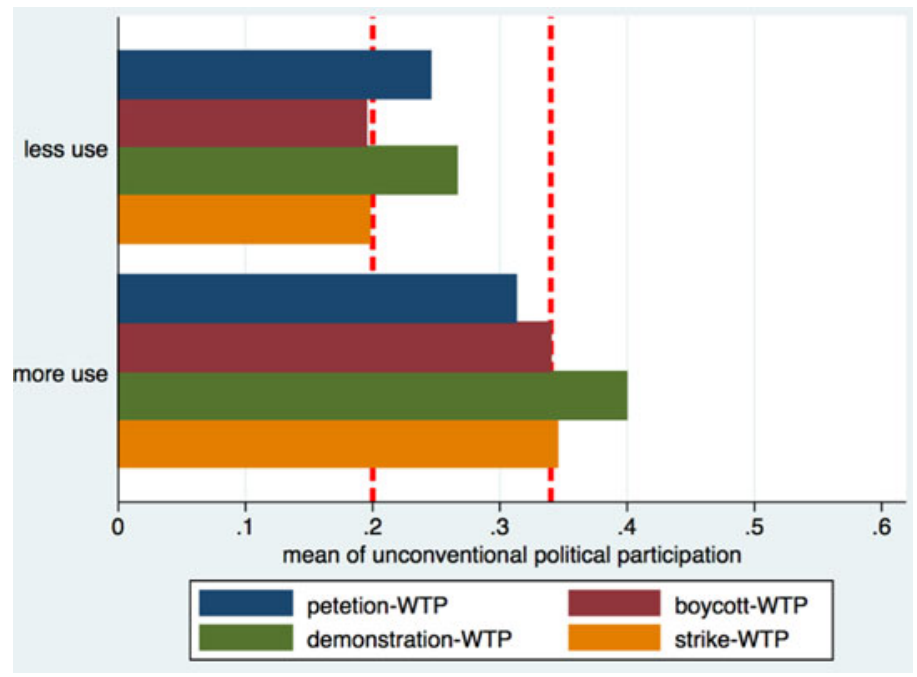

Appendix E.2. Difference in political expression (HD) by Internet usage.

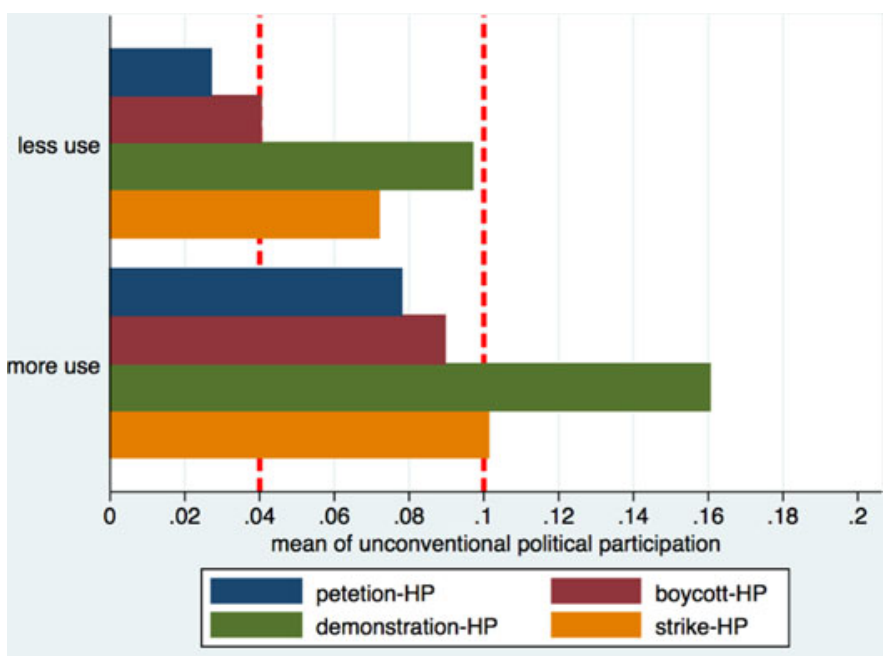


Appendix F. Covariates adjustment by entropy balancing

\begin{tabular}{|c|c|c|c|c|c|c|}
\hline \multirow[b]{2}{*}{ Covariates } & \multicolumn{3}{|c|}{ Treat $=$ high use } & \multicolumn{3}{|c|}{ Control = low use } \\
\hline & Mean & Variance & Skewness & Mean & Variance & Skewness \\
\hline \multicolumn{7}{|l|}{ Before weighting } \\
\hline Age & 37.970 & 230.800 & 0.672 & 44.960 & 288.600 & 0.330 \\
\hline Gender & 0.521 & 0.250 & -0.085 & 0.453 & 0.248 & 0.189 \\
\hline Financial satisfaction & 6.302 & 5.181 & -0.467 & 5.687 & 6.286 & -0.169 \\
\hline Political interest & 2.473 & 0.895 & -0.072 & 2.305 & 0.931 & 0.120 \\
\hline Educational level & 1.384 & 0.362 & -0.411 & 0.813 & 0.421 & 0.204 \\
\hline Post-materialism & 0.831 & 0.392 & 0.141 & 0.634 & 0.360 & 0.363 \\
\hline Petition & 1.924 & 0.683 & 0.142 & 1.479 & 0.488 & 1.125 \\
\hline Boycott & 1.516 & 0.429 & 0.897 & 1.266 & 0.271 & 1.832 \\
\hline Demonstration & 1.716 & 0.522 & 0.487 & 1.447 & 0.434 & 1.175 \\
\hline Strike & 1.542 & 0.446 & 0.841 & 1.333 & 0.360 & 1.621 \\
\hline \multicolumn{7}{|l|}{ After weighting } \\
\hline Age & 37.970 & 230.800 & 0.672 & 37.970 & 232.800 & 0.791 \\
\hline Gender & 0.521 & 0.250 & -0.085 & 0.521 & 0.250 & -0.084 \\
\hline Financial satisfaction & 6.302 & 5.181 & -0.467 & 6.302 & 5.566 & -0.396 \\
\hline Political interest & 2.473 & 0.895 & -0.072 & 2.473 & 0.918 & -0.065 \\
\hline Educational level & 1.384 & 0.362 & -0.411 & 1.383 & 0.366 & -0.423 \\
\hline Post-materialism & 0.831 & 0.392 & 0.141 & 0.831 & 0.402 & 0.156 \\
\hline Petition & 1.924 & 0.683 & 0.142 & 1.924 & 0.673 & 0.141 \\
\hline Boycott & 1.516 & 0.429 & 0.897 & 1.516 & 0.455 & 0.946 \\
\hline Demonstration & 1.716 & 0.522 & 0.487 & 1.716 & 0.553 & 0.511 \\
\hline Strike & 1.542 & 0.446 & 0.841 & 1.542 & 0.496 & 0.914 \\
\hline
\end{tabular}




\section{Appendix G. Robust check with entropy weighting}

\begin{tabular}{|c|c|c|c|c|c|c|}
\hline & (1) & $(2)$ & (3) & (4) & (5) & (6) \\
\hline Internet usage (never use $=0$ ) & $\begin{array}{l}-0.079^{\star \star \star} \\
(0.013)\end{array}$ & $\begin{array}{l}-0.125^{\star \star \star} \\
(0.027)\end{array}$ & $\begin{array}{l}-0.066^{*} \\
(0.040)\end{array}$ & $\begin{array}{l}-0.265^{\star \star \star} \\
(0.043)\end{array}$ & $\begin{array}{l}-0.227^{\star \star \star} \\
(0.035)\end{array}$ & $\begin{array}{l}-0.197^{\star \star \star *} \\
(0.039)\end{array}$ \\
\hline Internet usage $\times$ democracy & $\begin{array}{l}0.006^{\star * \star} \\
(0.002)\end{array}$ & & & & & \\
\hline Degree of democracy & $\begin{array}{l}-0.022^{\star \star} \\
(0.005)\end{array}$ & $\begin{array}{l}-0.015^{\star \star} \\
(0.006)\end{array}$ & $\begin{array}{l}-0.021^{\star} \\
(0.005)\end{array}$ & $\begin{array}{l}-0.002^{\star \star} \\
(0.005)\end{array}$ & $\begin{array}{l}-0.012 \\
(0.016)\end{array}$ & $\begin{array}{l}-0.011 \\
(0.016)\end{array}$ \\
\hline Internet usage $\times$ petition index & & $\begin{array}{l}0.054^{\star \star \star} \\
(0.016)\end{array}$ & & & & \\
\hline Expression index: petition & & $\begin{array}{l}-0.190 \\
(0.177)\end{array}$ & & & & \\
\hline Internet usage $\times$ boycott index & & & $\begin{array}{l}0.021 \\
(0.030)\end{array}$ & & & \\
\hline Expression index: boycott & & & $\begin{array}{l}0.088 \\
(0.272)\end{array}$ & & & \\
\hline Internet usage $\times$ demonstration index & & & & $\begin{array}{l}0.148^{\star \star \star} \\
(0.028)\end{array}$ & & \\
\hline Expression index: demonstration & & & & $\begin{array}{l}-0.755^{\star \star \star} \\
(0.040)\end{array}$ & & \\
\hline Internet usage $\times$ strike index & & & & & $\begin{array}{l}0.136^{\star \star \star} \\
(0.025)\end{array}$ & \\
\hline Expression index: strike & & & & & $\begin{array}{l}-0.382^{\star} \\
(0.023)\end{array}$ & \\
\hline Internet usage $\times$ average expression index & & & & & & $\begin{array}{l}0.110^{\star \star \star} \\
(0.027)\end{array}$ \\
\hline Average expression index & & & & & & $\begin{array}{l}-0.393^{\star} \\
(0.013)\end{array}$ \\
\hline Other variables controlled & Yes & Yes & Yes & Yes & Yes & Yes \\
\hline Entropy weight & Yes & Yes & Yes & Yes & Yes & Yes \\
\hline
\end{tabular}

Note: 1 . Rrobust standard errors in parentheses, and statistical significance reported as: ${ }^{*} P<0.1,{ }^{* \star} P<0.05$, ${ }^{\star \star *} P<0.01 ; 2$. The variable of Internet usage is a dummy variable and never use $=0 ; 3$. For all models, we control all other individual-level and country-level variables.

Cite this article: You Y, Wang Z (2020). The Internet, political trust, and regime types: a cross-national and multilevel analysis. Japanese Journal of Political Science 21, 68-89. https://doi.org/10.1017/S1468109919000203 